\title{
Interpretation in Law: The Dworkin-Fish Debate (Or, Soccer Amongst the Gahuku-Gama)
}

In a recent article, entitled Law as Interpretation, ${ }^{1}$ Professor Ronald Dworkin investigates the nature of legal analysis by developing certain analogies to literary practice. He proposes as a metaphor the chain novel, a single story composed by a sequence of authors, to depict how new cases might be resolved in law. Much as each author of a new chapter must develop themes suggested in the fictional work begun by his predecessors, so "[e]ach judge must regard himself, in deciding the new case before him, as a partner in a complex chain enterprise of which these innumerable decisions, structures, conventions, and practices are the history."2 Each new holding must carry forward precedent by advancing principles and policies inherent in the law as a whole; each new chapter in a chain novel must realize the promise of the work's beginnings by helping to make the novel the "best" work of art it can be.

A judge confronting a "new" case does so in a developing historical context, composed of precedents that have increasingly elaborated and focused the key principles in that area of the law, much as a novelist writing a late chapter in a chain novel starts out with a plot and characters already in place. Both judges and novelists are limited in adding new material to their chain enterprises by what they will see as the most coherent view of the practice up until then. In Dworkin's terms, the judge's or novelist's sense of the integrity and coherence of the "practice

1. Professor Dworkin's article, Law as Interpretation, first appeared in 9 CRITICAL INQUIRY 179 (1982). Professor Fish's response, Working on the Chain Gang: Interpretation in the Law and in Literary Criticism, is initially discussed infra in text accompanying notes 7-11, and also first appeared in 9 CRITICAL INQUIRY 201 (1982). Both Dworkin's and Fish's articles appeared later in a symposium on interpretation, Symposium: Law and Literature, 60 TEX. L. REV. 527 (1982); id. at 551. Dworkin's article is reprinted as Law as Interpretation, in THE POLITICS OF INTERPRETATION 249 (W.J.T. Mitchell ed. 1983) [hereinafter cited as Dworkin, Law as Interpretation]. Fish's reply is reprinted as Working on the Chain Gang: Interpretation in the Law and in Literary Criticism, in THE Politics of INTERPRETATION, supra, at 271 [hereinafter cited as Fish, Working on the Chain Gang]. Dworkin's response to Fish is reprinted as well, titled My Reply to Stanley Fish (and Walter Benn Michaels): Please Don't Talk about Objectivity Any More, in ThE POLITICS of INTER PreTATION, supra, at 287 [hereinafter cited as Dworkin, My Reply]. A related article by Professor Walter Benn Michaels, which comments on Dworkin's first article, is included in the same collection. Michaels, Is There a Politics of Interpretation?, in THE PoLITICS OF INTERPRETATION, supra, at 334. All subsequent references to these articles will be to THE POLITICS OF INTERPRETATION.

2. Dworkin, Law as Interpretation, supra note 1, at 263. 
. . . as a whole" will "tutor and constrain" him, guiding him to produce right decisions or good art. ${ }^{3}$

A judge or chain-novelist must not "strike out in some new direction of his own"; he must not set out to make law or to write his owu work of fiction. Rather, each acts as part of a collective, chain effort and performs his task most faithfully when he extends the logic of what went before, focusing and clarifying what has already evolved as the "point or value" within "that practice."5 The image of a chain suggests for Dworkin not merely a sequence, but a progress. Judicial or literary choices are never merely mechanical even at the end of a long string of cases or chapters. But there will be fewer possible reasonable conclusions as a body of legal doctrine or a work of literature develops. Calculating the best resolution of a legal issue or novel becomes easier as precedent accumulates and issues are tested and retested. In this way, increasingly, the constraints of local context euable the conscientious judge or author to arrive at the right answer. ${ }^{6}$

Having ventured into the territory of literary interpretation, Dworkin has been challenged by a literary critic who has in recent years himself crossed disciplines by undertaking to discuss the nature of legal interpretation. In an answer to Dworkin, pointedly titled Working on the Chain Gang, ${ }^{7}$ Professor Stanley Fish argues that neither legal nor novelistic interpretation can be conceived of as a chain-like enterprise. Fish asserts that interpretative alternatives do not diminish as chain novels are passed from author to author, or as legal doctrine develops through time. History weighs no more heavily on the new interpreter than it did on his predecessors: constraints "do not relax or tighten in relation to the position an author happens to occupy on the chain."8

For Fish, the interpreter's view of his antecedents is not intellectually separable in any important way from his view of his own purpose. The interpreter is not constrained by the past; he recreates it as he develops his new theory. ${ }^{9}$ In legal disputes, Fish implies, both the principles that apply to the case and the facts of the case are equally creations of the interpreter: how a judge finds principles or sees facts depends on the argument he believes he must make. An interpreter does not first come to an understanding of what went before and then attempt to reconcile his view of a present problem with that established practice. In each act of interpretation, a judge's or author's perception of what has gone before is
3. Id. at 264,265 .
4. Id. at 263-64.
5. Id. at 264 .
6. Id. at 265-66.
7. Fish, Working on the Chain Gang, supra note 1, at 271.
8. Id. at 274.
9. Id. at 275 . 
as much the consequence of interpretation as is a new case or a pending novelistic development. Fish asserts that "interpretation has already done its work" when the principles of interpretation and the facts to be interpreted are perceived. ${ }^{10}$ In terms of Dworkin's metaphor, the "chain" of interpretation is forged anew with each interpretation: "To see a present-day case as similar to a chain of earlier ones is to resee that chain by finding in it an applicability that had not always been apparent." In short, for Fish there is no chain.

Where Dworkin conceives a chain of interpretations that allows a hard case to come closer and closer to an easier one, Fish sees only discrete cases. For Dworkin, as new facts are fitted to the same story, elements will more readily add up as predicted and the "best" implications of that legal or literary enterprise will be realized. For Fish, a series of readings is not linked together in a lengthening chain, but is instead a sequence of discrete structures. Legal or literary interpretation is not a matter of continuing an old story; rather, there is always a wholly new story replacing the old. That is not to say that the judge or novelist is free to choose his own result in an arbitrary or capricious way. Indeed, the judge or novelist never chooses an interpretation at all. As a member of an intellectual community-whether it be the legal or literary profession-he will merely "see" the conclusion he necessarily regards as "best." The rightness of his answer will be verified in the only way possible: by the degree to which it is persuasive within his intellectual community. ${ }^{12}$

Dworkin and Fish appear to be at fundamental odds: Dworkin claims that history, a lengthening chain of decisions and events, creates a constraining context for decisionmaking; Fish argues that each new decision recreates history, forging the conceptual chain anew. And their initial debate over the analogy between legal interpretation and chain novels has broadened, through a series of articles by these two principals and by partisans who have joined the fray on both sides, ${ }^{13}$ into what is finally an

\footnotetext{
10. Id. at 274 .
}

11. Id. at 277. Fish disputes Dworkin's notion that a judge "strikes out in a new direction" when he fails to advance the chain enterprise according to what legal history dictates. In Fish's view, Dworkin is falsely reifying precedent on the one hand, and suggesting an interpretive freedom judges never have on the other. Judicial history and the judge's sense of the case at hand emerge together, so that precedent cannot act as a constraint and a judge cannot proceed in a direction that is not already implicit in the juridical enterprise. What Dworkin distinguishes as following legal history from striking out in a new direction are for Fish both ways of continuing the practice. So long as a judge offers what the judicial interpretive community would recognize as competent grounds for a decision, no holding is ruled out in advance. "Striking out in a new direction" is merely what we accuse people of when we disagree with their conclusions. Id. at 278; see also Dworkin's recent discussion of judicial decisionmaking in Reagan's Justice, N.Y. REv. Books, Nov. 8,1984 , at 27.

12. Fish, Working on the Chain Gang, supra note 1, at 274-78.

13. See, e.g., Bruns, Law as Hermeneutics: A Response to Ronald Dworkin, in THE Politics 
attempt to characterize the morality of the legal decisionmaking process. Dworkin and Fish have each modified their initial positions and have come closer to intellectual agreement, even as the tone of their essays has become increasingly disagreeable. It is not enough for each to convince the other. Each appears to want to exorcise the very possibility of the other's position. This is because that position seems, for each, to be based on morally dangerous premises: Dworkin regards Fish as precluding the possibility of rational discourse $;{ }^{14}$ Fish regards Dworkin as oversimplifying interpretation by reifying a fixed standard of "truths" and is unmoved by Dworkin's fervent disavowal of any metaphysics behind his objectivism. ${ }^{15}$

In fact, each side is an antidote to the real moral dangers of the other. Their views must be taken together to form a comprehensive picture of legal decisionmaking that avoids the pitfalls of mere rhetoric or mere positivism. This Comment argues that it is best not to elevate one side over the other in this debate. An appreciation of each is essential to a sophisticated understanding of legal hermeneutics. On the one hand, Dworkin envisions what this Comment terms a "judge model" of legal interpretation, in which an adjudicator seeks the "best" (most coherent and integrated) reading of a case guided by a context of contingent premises and principles. On the other, Fish offers a "lawyer model" of legal interpretation, in which discrete arguments constitute legal practice, and "forceful and polemic urging of particular points of view is the means, and the only means, by which the truth is established."16

Part I of this Comment discusses further the underlying dispute between Dworkin and Fish, detailing the judge-lawyer distinction and the limits of each model seen independently of the other. Part II explores the disputed "chain" metaphor by examining a classic torts case, Palsgraf v. Long Island Railroad. ${ }^{17}$ In explicating the contrary statements of Justices Cardozo and Andrews about this case, Part II examines certain writings of Claude Lévi-Strauss, a structural anthropologist who has also studied story as if it were law and law as if it were story. The categories Lévi-Strauss develops for two types of human thinkers, the

OF INTERPRETATION, supra note 1, at 315; Graff, "Keep off the Grass," "Drop Dead," and Other Indeterminacies: A Response to Sanford Levinson, 60 TEx. L. REv. 405 (1982); Graff, The PseudoPolitics of Interpretation, in THe Politics of INTERPRETATION, supra note 1, at 145; Hirsch, The Politics of Theories of Interpretation, in THE POLITICS OF INTERPRETATION, supra note 1, at 321; Levinson, Law as Literature, 60 TEx. L. Rev. 373 (1982); Michaels, supra note 1, at 335; Said, Opponents, Audiences, Constituencies, and Community, in THE POLITICS OF INTERPRETATION, supra note 1 , at 7.

14. Dworkin, My Reply, supra note 1, at 303.

15. Fish, Wrong Again, 62 TEX. L. REv. 299, 301-02, 309 (1983).

16. Fish, Interpretation and the Pluralist Vision, 60 TEX. L. REV. 495, 501 (1982); see infra note 22.

17. 248 N.Y. 339,162 N.E. 99 (1928). 
bricoleur and the scientist, reveal the seemingly incompatible views of Dworkin and Fish as complementary intellectual products. This Comment concludes that the dispute between Dworkin and Fish is explicable in terms of the same bricoleur-scientist distinction, and suggests the complementary need for the distinct perspectives of both bricoleur and scientist, lawyer and judge, within our legal system.

\section{SlipPing Past Scylla and Charybdis}

\section{A. Steering a Middle Course}

The purpose of a theory of legal interpretation might be to characterize a moral kind of legal decisionmaking and to counter charges that lawyers and judges necessarily represent narrow partisan interests. In his answer to Dworkin's Law as Interpretation, Fish identifies the two pitfalls, the Scylla and Charybdis as it were, of both literary and legal interpretation: on the one hand, the belief, held by literary formalists and legal positivists, that interpretation is constrained by what is in the text; on the other hand, the belief, held by skeptics and some legal realists, that interpretation is just a rationalization of subjective desires and motives. ${ }^{18}$

These pitfalls are clearly as much moral as intellectual. To defend against skepticism, formalists have insisted that there is a "true" text which critics aim to make perceptible. Thus, the formalist critic Professor E.D. Hirsch argues that "validity in interpretation" requires a stable, canomical text. He suggests that only if we believe in an external standard, an objective, fixed, historical text, can we verify our personal political premises about it. ${ }^{19}$ Arguing similarly, Professor Owen Fiss asserts that legal interpretation requires a belief in a transcendent set of norms, an "objective" constitutional text, to avoid "the slide toward nihilism."20

On the other side is a group of literary and legal critics who would portray Hirsch and Fiss as wishful thinkers. ${ }^{21}$ Critics of this sort deny

18. Fish, Working on the Chain Gang, supra note 1, at 275.

19. See E.D. HirSCH, JR., VALIDITY IN INTERPRETATION (1967); see also Hirsch, supra note 13, at 329. Hirsch articulates his critical stance by analogizing the critic's choice to Pascal's wager when confronted by the impossibility of demonstrating that God exists: "Let us weigh the gain and loss in calling heads-that God exists . . . . If you win, you win everything. If you lose, you lose nothing. Do not hesitate then, gamble on his existence." Id. (quoting THE PENSEEs no. 451 (J.M. Cohen trans. 1961)). Hirsch paraphrases, substituting objective historical truth for God. He argues that ultimately the question of objective truth, unresolvable as an epistemological issue, is political and ethical, the question being, "What sort of culture do we want to foster?" Id. at 330.

20. Fiss, Objectivity and Interpretation, 34 STAN. L. REV. 739, 750 (1982).

21. See, e.g., J. Culler, Structuralist Poetics (1975); P. DE MaN, Blindness and INSIGHT: ESSAYS IN THE RHETORIC OF CONTEMPORARY CRITICISM (2d rev. ed. 1983); G.H. HARTMAN, The FATE OF REAdiNg AND OTHER EsSAYS (1975); Levinson, supra note 13. 
the validity of treating text as canon. Just as words are never themselves identical with what they describe, these critics hold that an interpretation is at once identifiable with, yet separable from, the text it represents. Thus, the aim of interpretation cannot be a direct apprehension of a canonical text. At the extreme, this view implies that all discourse is "representative," that it never apprehends objects directly, and that therefore knowledge is "fractured and fragmented."22 Skeptical critics imply that interpretations cannot command authority by being "correct": interpretative authority is conferred only by the force of institutions. Fiss not surprisingly is disturbed by the authoritative implications he detects im the expressions of such skepticism about interpretation. ${ }^{23}$

Both Fish and Dworkin set out to steer a middle course, to slip past the Scylla of positivistic oversimplification and the Charybdis of intellectual indeterminacy. Both demand a view of interpretation that is at once complex and moral. Interpretation can be moral because there can be "right" answers. This is what Fish means when he insists, "Mine is not an argument for an infimitely plural or open text, but for a text that is always 'set." "24 Within each set of interpretative assumptions, there is a stable and unambiguous text. Dworkin similarly concludes that "[f]or all practical purposes, there will always be a right answer in the seamless web of our law."25

But neither Fish nor Dworkin enunciates simple criteria for the verification of interpretations. Rather, they agree that authority for interpretations comes through processes that are complex, communal, and political. That is, interpretations become "correct" as they become social objects. The "political" aspect of legal interpretations, far from being the perverting force simple positivists would portray it to be, is what makes those interpretations correct. In Dworkin's scheme, the judge's goal is a political one: the judge "identifies a particular conception of community morality as decisive of legal issues."26 Fish argues that political

22. Levinson, supra uote 13, at 403 . Levinson cites Fish in support of his own "radical" pluralism in response to what he sees as the instability of ineaning. Id. at 381,384 . Fish, however, disclaims Levinson as a student of his ideas, charging instead that Levinson's position "is in crucial ways the mirror inage of Dworkin's." Fish, supra note 16, at 495; see also M. Walden, Word, Innage, and Representation (1981) (uupublished dissertation, University of California, Berkeley).

23. Fiss, supra note 20 , at 741-48. Fiss writes that for the "new nihilis[ts] . . [a]ll law is masked power." Id. at 741. Among these new nihilists, Fiss numbers the hiterary critics of the "destruction movement." Id. at 741 n.9. Not surprisingly, Fish returns the charge, pointing to the police-state imagery of Fiss' own vision of the "disciplining rules" of legal interpretation. Fish, Fish vs. Fiss (forthcoming in volume 36 of the Stanford Law Review).

24. S. Fish, Normal Circumstances, in Is There a TeXt In This Class?: The Authority of INTERPRETIVE COMMUNITIES 268, 274 (1980) [hereinafter cited as Is ThERE A TEXT IN ThIS Class?].

25. Dworkin, No Right Answer, in LAw, MORALITY AND SocIETY 58, 84 (P. Hacker \& J. Raz eds. 1977).

26. R. Dworkin, Hard Cases, in TAking Rights Seriously 81, 126 (rev. ed. 1978). 
processes lend all interpretations their form: "The entire system is political and the question at any moment is from which point in the system is pressure being applied to what other points."27

Yet, even though they agree that interpretations must be both correct and communal, Dworkin and Fish are certainly not happy fellow travelers through the middle course between Scylla and Charybdis. Each is eager to condemn the other's intellectual wanderings and to demonstrate that the other has wrecked his argument in the very pitfalls he set out to avoid. The source of their dissent is evident in the very language they use to describe similar models of the social basis for interpretive structures. Fish would assert that Dworkin's phrase "particular conception of community morality as decisive of legal issues" gives the game away, because it suggests that a judge can understand that morality before he turns to the particular legal issue he must decide. In other words, morality would constrain decisions, rather than being created through them. Dworkin would object to Fish's contention that the "entire system is political" because it suggests that the process is partisan and does not necessarily represent what is best for society as a whole.

Each accuses the other of falling prey to morally abhorrent reductive simplicities, and worse. Dworkin charges Fish with harboring "hidden and malign" skeptical dogmas, and diagnoses "Fish's inability to read my essay" as a function of the "skeptical wreck he has made of interpretation." 28 Fish says that, protests to the contrary, Dworkin is indeed a positivist and that in his defenses against that charge Dworkin is merely "wrong again." 29 Furthermore, Dworkin announces his own inability to "make any sense of" Fish's essay at crucial points. ${ }^{30}$ In short, Fish argues that Dworkin has capsized on Scylla, and Dworkin claims Fish has been engulfed in Charybdis.

The vulnerability of each of these writers to particular attacks, and their propensities to attack each other in particular ways, reflect in each case the differing concerns of their separate academic disciplines. Dworkin, for instance, develops his theory of how judges resolve "hard cases" in response to legal positivists who argued that a judge applies established rules until they run out and then acts with discretion. His primary goal is to purge judicial decisionmakers of any connotation of capriciousness. He maintains that there is always a right answer-even if a controversial one-dictated by legal principles, not arrived at arbitrarily. Fish's goal is both personal and professional. He wants to merge discretion and capriciousness. By proving that they are the same thing,

27. Fish, supra note 23 .

28. Dworkin, My Reply, supra note 1, at 287, 290, 296.

29. Fish, supra note 15 , at 299.

30. Dworkin, My Reply, supra note 1, at 296. 
he can allow for his own changes of mind, and for the multiplicity of conflicting interpretations that he and his colleagues generate, without admitting error. Any answer that is arrived at will be "right," but only because it must be arrived at by mental processes that are socially verified. The professional "community"- be it academic, critical or legallends its members the social and political authority to say which readings are "correct." At the practical level, it is this authority that English and law professors wield over recalcitrant first-year students who insist they are just as right about what a poem or a case means as their teachers.

With these differing emphases, therefore, Dworkin and Fish reflect the concerns of their own bailiwicks. The judge's dedication to continuity, as portrayed by Dworkin, is unsettling to Fish as a model for literary criticism. On the other hand, the literary critic's facility with multiplying interpretations and distinguishing any one set of facts from another is unsettling to Dworkin because it makes every case equally hard regardless of how much precedent has accumulated. It undermines the possibility of settling upon the "best" view of any legal doctrine by saying there will always be another, contrary reading. Law and literary criticism differ in just this respect: literary criticism imagines a protean text; law aims toward codification. Literary criticism fosters increasing spinoffs of new interpretive communities, while law aims toward expanding the interpretive community to embrace society as a whole. ${ }^{31}$ Or at least, while legal academics are as divided and divisive as literary critics, judges have a stake in greater uniformity. This distinction between the two, seen as a function of their different intellectual communities, is reflected even in their styles. Dworkin's Oxfordian presentation makes him sound to Fish like the positivists; Fish's impish literary flair for paradox and inversions like "[d]isagreements are not settled by the facts, but are the means by which the facts are settled"32 makes him sound like a fashionable quasi-skeptic to Dworkin. ${ }^{33}$

Neither writer is completely convincing in the claims he makes for his picture of interpretation. If, as Dworkin contends, each judgment forges a link in a chain connecting all judgments, it is only because law

31. It is thus easy for a literary critic to come up with examples of the very thing Dworkin dismisses as out of the question, such as a reading of Hamlet without the Prince. Dworkin, The Forum of Principle, 56 N.Y.U. L. REv. 469, 475 (1981) ("The idea of the Constitution as fundamental law is so cemented into the common assumptions that constitute our legal order that an interpretation which denies it would be an interpretation of something else altogether, like ... an interpretation of Hamlet that ignored the Prince."). Tom Stoppard's ROSENCRANTZ \& GUILDENSTERN ARE DEAD (1967) is just such an "impossible" reading. Similarly, Fish deftly undermines Dworkin's attempts to assert any "givens" in Dickens, Milton, or Agatha Christie criticism.

32. S. Fish, What Makes an Interpretation Acceptable?, in Is THERE A TEXT IN THIS Class?, supra note 24 , at 338.

33. Dworkin, My Reply, supra note 1, at 287. 
itself is a "seamless web," a totality of principles that can be applied to every case, and because a judge is a "Hercules," 34 omniscient so that principles can be applied without errors. Dworkin betrays his uncertainty about these implications of his own argument when he writes in Hard Cases that "law may not be a seamless web; but the plaintiff is entitled to ask Hercules to treat it as if it were."35 A judge may not always find direct legal precedent that will enable him to justify a decision he nonetheless sees as correct. "It may be," as Dworkin notes, "that [a] new principle strikes out on a different line, so that it justifies a precedent or a series of precedents on grounds very different from what their opinions propose."36 Dworkin cites Justices Brandeis' and Warren's finding of a constitutional right to privacy as an example of this, noting that their argument was "at least sound in its ambition" even if some observers view it as a kind of "brilliant fraud."37 Similarly, total consistency of new decisions with past precedent is sometimes impossible, and some parts of institutional history may have to be dismissed as mistaken. In both cases, judges might practice a kind of "brilliant fraud," but one that is sound insofar as it enables them to find the right answers to hard cases. Such opinions can still be seen as "best" if they have been generated as part of a Herculean effort to comprehend the "seamless web" of law.

Fish, too, is vulnerable. He says there is no need to concern ourselves with the unverifiability of the truths we assert because we will always necessarily believe what we believe. It is ironic that this notion that truth is merely a matter of persuasion should come from Fish, whose first important studies were of Milton. ${ }^{38}$ In Paradise Lost, Satan is the expert rhetorician, while only a reader who listens for the "truth" can hear the message of God's word. ${ }^{39}$ Dworkin perceptively observes that Fish cannot really believe that persuasion is everything: "No one who has a new interpretation to offer believes his interpretation better because it will convince others, though he may believe it will convince others because it is better." 40 It is Fish's own anxiety about what "reality" might be, Dworkin claims, that drives Fish to insist that others have an unacknowledged dependency on that concept. ${ }^{41}$

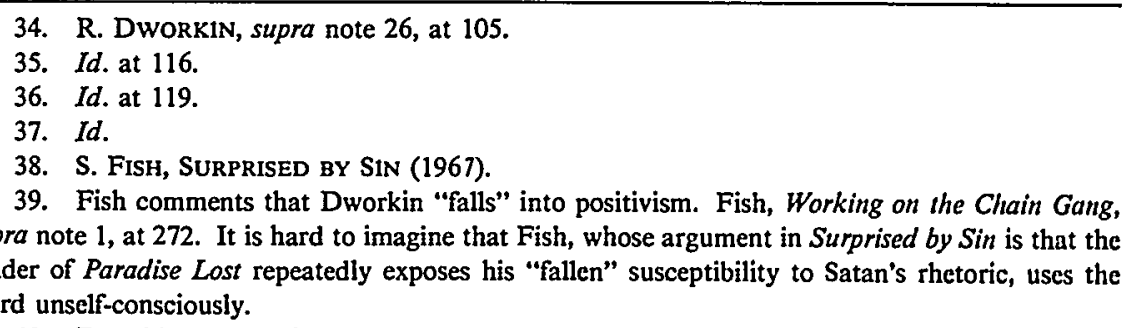

40. Dworkin, My Reply, supra note 1, at 297.

41. Id. Professor John Searle makes a similar point about the unacknowledged positivist as- 


\section{B. Judge and Lawyer}

Because of the violence of their verbal parry and thrust, it is tempting to declare one of these critics the victor. Dworkin appears to score points when he criticizes Fish's oversimplification of the interpretive process as something that cannot be psychologized or parsed because it has "always and already" occurred. ${ }^{42}$ Fish's view that interpretations and the principles supporting them are inextricably merged seems counterintuitive to the basic premise that legal reasoning is a matter of testing new conclusions against principles settled by previous interpretations. At best, Fish appears to be stating the obvious, that all meaning is man-made and that we know "right" or "wrong" answers only within a particularized social and historical setting. At worst, he appears to be denying the possibility for reasoned give-and-take when he declares that the only test for an interpretation is how much applause it receives from its hearers-a kind of "Queen for a Day" approach to deciding what is "best."

However, this view of Fish involves an oversimplification. It is as reductive to dismiss Fish as an immoral quasi-skeptic as it is to lump Dworkin with his positivist teachers, whose limitations Dworkin has devoted himself to demonstrating. Instead, both of these thinkers, through their efforts to avoid the dangerous antipodes of positivism and skepticism, contribute to a description of judicial interpretation that is at once comprehensive, moral, and sophisticated.

Fish writes that an effort at interpretation succeeds or fails depending on whether "[some]one else would be persuaded to my reading," position he is forced into by his claim that hypotheses cannot be tested since they emerge at the same time as the facts which they explain. By this account, when the hypothesis changes, so do the "facts." Fiss and Dworkin believe that this position elevates rhetoric over reason, prizing verbal posturing over scientific method. But the value of Fish's argument becomes clear when we understand the meaning to him of terms like "persuasion" and "rhetoric." As a literary critic, especially as one specializing in Renaissance literature, Fish knows the rich Aristotelian and Ciceronian tradition in which rhetoric and reason are not opposed, a tradition that in fact directly underlies modern legal practice.

Rhetoric in this tradition is not only moral, it is the means by which the morality of the community is perpetuated. The goals of rhetoric are to teach and to convince; reason is the crucial tool for achieving these goals. Students are reached through pleasing words in order to be con-

sumptions of post-structuralist literary critics in The Word Turned Upside Down, N.Y. REv. Books, Oct. 27,1983 , at 74,78 .

42. See Fish, Working on the Chain Gang, supra note 1, at 281.

43. Id. 
vinced of moral principles. Arguments are made about cases so that communal values can be understood. "Mere rhetoric" is not rhetoric at all by these standards, because rhetoric stripped of reason cannot be convincing. Therefore, Fish emphasizes that through persuasion we apprehend reason and understand law, not that law is incomprehensible and forever obscured by facile argumentation.

Fish's contribution to our understanding of legal interpretation is the alleviation of a fear reflected by Fiss, and one that permeates the layperson's view of the legal process: the fear that if two lawyers are arguing before a judge and only one of them will win his case, then one of the lawyers must be a hypocrite who does not and indeed cannot really believe what he is saying. If the judge makes the "right" decision it is because he has seen through the mere rhetoric of that lawyer; if he makes the "wrong" decision it is because he has been swayed by that rhetoric. In fact, Fish enables us to see how lawyers in hard cases (and almost all cases are hard cases) can sincerely believe in their rhetoric. Lawyers can argue both sides not because one of them is arbitrary or unethical, but because of the different assumptions each brings to the case. Within the shared assumptions of the interpretive community of those who "think like lawyers," there is almost always the possibility for argument about what the law on a particular issue is and what the facts of the case add up to. Each lawyer is charged with presenting the most persuasive case for his view of the law and the facts. Thus, even while he argues a partisan opinion, a lawyer serves a social purpose. The lawyer must adhere to the "general interpretive conditions" of his enterprise; he must observe the profession's "stipulations as to what counts as evidence, as to what will be heard as a properly [legal] argument." 44 And in so doing he aids in the delivery to society of its own moral precepts: "the forceful and polemic urging of particular points of view is the means, and the only means, by which the truth is established." 45

In a challenge to Fish, entitled Offending the Profession, ${ }^{46}$ literary critic Walter Davis points to the necessary counterbalance Dworkin's model of legal reasoning offers. Fish shows that lawyers can confidently and without cynicism hold almost whatever opinion serves a client's in-

44. Fish, Fear of Fish: A Reply to Walter Davis, 10 CRITICAL INQUIRY 695, 699 (1984); sec infra note 46.

45. Fish, supra note 16 , at 501.

46. Davis, Offending the Profession (After Peter Handke), 10 Critical INQuiry 706 (1984) [hereinafter cited as Davis, Offending the Profession]. Davis was responding to an article by Fish, supra note 44, which was itself a response to Walter Davis' The Fisher King: Wille zur Macht in Baltimore, also appearing in 10 CRITICAL INQUIRY 668 (1984). Although the profession Fish "offends" according to Davis is that of the English professor (at John Hopkins University in Baltimore), this exchange bears directly on an understanding of Fish's debate with Dworkin over interpretation in law. 
terests. But Davis argues for the moral necessity of heeding the anxiety that Fish rules out. Interpreters must think that they can be wrong, Davis writes, so that the interpretive process will continue to serve the community. ${ }^{47}$ We must elevate the Constitution above arguments about it, so that we can continue to measure our laws by it. In literary terms, we cannot fully believe Fish's argument that the critic brings the text into being; in Davis' phrase, the critic must also believe that "Shakespeare [i.e. the text] measures me."48 Just as Davis' critic can be the "humble servant of the text," ${ }^{, 49}$ desiring to prove worthy of the experience of the literary work, in law the judge is the social embodiment of humbleness and anxiety before the text, letting the law decide the case, not the case establish the law.

Dworkin describes legal interpretation as an effort to meet the challenge of arriving at a decision that is not only plausible, but "best." For Dworkin, a legal interpretation must not only "fit [the] practice," it must show its value as the "best principle or policy." or even possible in Fish's scheme. For Fish, anything that fits the practice will necessarily be "best" since interpretation and analysis occur at once: "information only comes in an interpreted form . . . even when you first 'see' it, interpretation has already done its work." 51 Dworkin proposes a dialectical process, possible because the judge's sense of law is sufficiently structured and disjoined from particular cases. The judge can stand back from the immediate context and evaluate two different interpretations and then determine which best fits the practice.

The positions of Fish and Dworkin do not cancel each other out. They represent two different moments in a process. The lawyer, as zealous advocate, denies the possibility of alternative interpretations; in effect, he brings the law into being as he argues his case. Thus a legal text, such as the Constitution, has no reality that is separate from the argument that establishes the meaning of a particular case. When the application of the first amendment in particular cases changes, the first amendment itself changes. The judge, on the other hand, stands back and reflects on two arguments to determine which is "best." Neither Davis nor Dworkin contends that literary or legal texts reflect disembodied or positivist truths. But they require judges to take the broader prospective by asking the morally crucial question, "How do these arguments measure up to the Constitution?"

\footnotetext{
47. Davis, Offending the Profession, supra note 46, at 711-14.

48. Id. at 716-17.

49. Id. at 717.

50. Dworkin, Law as Interpretation, supra note 1, at 264.

51. Fish, Working on the Chain Gang, supra note 1, at 274.
} 
II

\section{The Fireworks IN THE PACKage}

Dworkin is drawn to literary criticism-and to literature, particularly Dickens' stories which he frequently uses to exemplify his arguments ${ }^{52}$-because he wants to explain the "creative" aspect of literary decisions, the aspect that allows some decisions to be better than others and that allows judges to disagree. Fish, on the other hand, looks to law not only to find a common ground with Dworkin, but also because he seeks for the literary critic a social sanctioning, an ability to make his judgments represent "truth" for his community. Part I commented upon the battle between Dworkin and Fish for the border area between law and literature. This Part shows how an appreciation of both their positions can provide a comprehensive understanding of historical legal events.

\section{A. Palsgraf}

Palsgraf v. Long Island Railroad ${ }^{53}$ offers an example of important judges proposing different readings of facts and principles. It presents to any interpreter an intriguing puzzle, one that one of its judges, Benjamin Cardozo, embellished and developed with much of the inventiveness Dworkin admires in Dickens. The tale is of a bizarre incident on the Long Island Railroad, and it offers an illustration of how facts "add up" and how cases are related to precedent. These are questions about how, or if, in this case a new link is to be forged in an existing chain. Dean Prosser has dubbed Palsgraf "a law professor's dream of an examination question," opinions offer an archetype of the legal dispute: both are compelling, but they are irreconcilable readings of a single story. And the opinions turn on what might be seen as an acceptance or rejection of the chain metaphor that Fish and Dworkin debate.

The fact summaries of Cardozo and Andrews demonstrate what every law student knows after writing a single brief: every statement of fact is also an argument and a proof. But, despite their succinctness, Cardozo's and Andrews' descriptions of the events are products, not objects, of their analyses. If the events on the Long Island Railroad platform are a kind of text, Cardozo's and Andrews' readings of them

52. See. e.g., Dworkin, supra note 25, at 58 (David Copperfield); Dworkin, Law as Interpreta. tion, supra note 1, at $262 \mathrm{n} .4$ (A Christmas Carol). Dworkin also peppers his argument with references to Hamlet and to such popular fiction as Fowles' French Lieutenant's Woman, Agatha Christie's detective novels, and Naked Came the Stranger, the parody pornographic "chain novel" that inspired his metaphor for legal interpretation.

53. 248 N.Y. 339,162 N.E. 99 (1928).

54. W. Prosser, HaNDBOOK OF THE LAW OF TORTS 254 (4th ed. 1971). 
demonstrate Fish's central tenet about interpretation: "interpretive strategies are not put into execution after reading; they are the shape of reading."5s A two-step process of describing and then interpreting is impossible because interpretation itself determines what will count as facts to be observed.

Cardozo's cinematic description of events emphasizes discontinuity. In the opening frame, the plaintiff is standing on a railway platform, awaiting a train for Rockaway Beach. In the next sentence, the mise en scène shifts: a train stops at a platform "bound for another place." 56 There, at a locus removed from that of the waiting Mrs. Palsgraf, occurs a rapid, almost slapstick, series of events involving four men and an innocent-looking parcel. Two men run forward and attempt to leap aboard a moving train. One boards safely, the other is unsteady, "as if about to fall." On the brink of disaster, the teetering man is rescued by two guards, who, in the process of pushing and pulling him, dislodge a package, which falls on the rails. The small, newspaper-wrapped package is inconspicuous; "nothing in its appearance [gave] notice of its contents." In fact, Cardozo remarks, "it contained fireworks," which explode on the rails. The shock throws down some scales "at the other end of the platform." We return to the first scene, that of the plaintiff awaiting her train to Rockaway Beach. The scales fall and strike the plaintiff, "causing the injuries for which she sues." The only clear and direct cause and effect linking the two distinct scenes occurs in the last sentence of the paragraph. There Cardozo suggests that somehow an instantaneous interchange between guards and an unsteady passenger has culminated in an injury to someone "many feet away" and "bound for another place." 57 Beginning with an evocative description of nonrelation, which he will go on to address under the notion of foreseeability, Cardozo has portrayed a disjointed series of unrelated incidents. There will be no basis, according to this narrative, for tracing any chain of causality among events.

Andrews, by contrast, offers an unelaborate sketch of the incident on the Long Island Railway platform. But his matter-of-factness is in fact proof of assumptions exactly opposite to Cardozo's: events that have occurred in this case, he suggests, are connected and integrally related. Andrews narrates a simple chain of consecutive events: "Assisting a passenger to board a train, the defendant's servant negligently knocked a package from his arms." 58 The package falls not merely "on the rails," but "between the platform and the cars"-

\footnotetext{
55. S. Fish, Introduction to Is THERE A TEXT IN THIS CLASS?, supra note 24, at 13.

56. Palsgraf, 248 N.Y. at 340,162 N.E. at 99.

57. Id. at 341,162 N.E. at 99 .

58. Id. at 347, 162 N.E. at 101 (Andrews, J., dissenting).
} 
both the plaintiff and the four men had occupied. The chain of events is direct. A package is negligently knocked from a passenger's arms; it falls; an explosion follows; a scale topples upon the plaintiff awaiting her train. The plaintiff in Andrews' account is part of a single scene, an "intending passenger." 59 Beginning by tracing the consequences of a negligent act, Andrews constructs an argument for the railroad's liability, culminating in a notion of proximate cause.

In the paragraphs that follow each statement of facts, Cardozo and then Andrews attempt to comprehend an unusual incident within a coherent legal framework that will define the implications of that incident for recovery by the plaintiff. This particular legal decision can be seen as one instance of legal interpretation in general, as characterized by Dworkin. From this perspective, the question will be whether the injury to Mrs. Palsgraf is a link in a chain of events that requires a finding of tortious liability. The decision on that issue, if Dworkin's picture of legal reasoning is correct, can forge one more link in the common law defining tortious action.

Andrews does in fact undertake to judge the case in these terms, and his answer on all counts as to whether a new link has been forged will be yes. Mrs. Palsgraf must be "made whole" by the logic of tort recovery, which provides a framework to encompass this injury and to stipulate its remedy. Cardozo, however, does not simply find that Mrs. Palsgraf inhabits neither a chain of causality nor of legal precedent. For him, in this case, as for Fish in general, no such chains could possibly exist. Cardozo argues that no direct physical chain of events has occurred, and no intellectually traceable sequence emerges from the incident. There are, in his account, two distinct spheres of interest-"the orbit of the danger,"60 which includes the four men and the package, and "the bounds of [Mrs. Palsgraf's] immunity." 61 These circles of interest do not intersect. They are "not even of the same order." 62 The "diversity of interests," Cardozo reasons, "emphasizes the futility of the effort to build the plaintiff's right upon the basis of a wrong to some one else." 63 Cardozo is reticent about affirming the existence of any structure of events. Such a structure would be needed to prove how the foreseeable had become actual, and then to prove how the railroad had been negligent. Without this structure, the alleged negligence evaporates; it is mere "negligence in the air." 64 In this case, where there are no intersecting interests, there can be no foreseeability and, thus, no duty of care: "Life will have to be made over, and

\footnotetext{
59. Id. at 347,162 N.E. at 102 (Andrews, J., dissenting).

60. Id. at 343,162 N.E. at 100.

61. Id. at 341,162 N.E. at 99.

62. Id. at 343,162 N.E. at 100.

63. Id.

64. Id. at 341,162 N.E. at 99 .
} 
human nature transformed, before prevision so extravagant can be accepted as the norm of conduct." 65

Where Cardozo fails to find a "relationship," an interaction between events, Andrews asks only whether negligence of the railroad is negligence "relative" to the plaintiff. In this difference between "relationship" and "relative," Andrews' case is proven for him. Whatever the events in this case have been, so long as they are related, they will necessarily demonstrate negligence toward the person in fact injured. Proof of "proximate cause"-a direct chain of events-is de facto proof of a conceptual chain of events-of foreseeability. For Andrews, negligence is not a concept directed at a particular individual within a predictable "radius of danger." A negligent act is a wrong to the world at large, and a defendant must account to those in fact injured. ${ }^{66}$

Andrews rejects Cardozo's metaphor of discrete spheres of interest. He offers instead that of a river, into which flow related events, like tributaries merging in a common stream. Although Andrews finally gives up his own metaphor as "rather rhetoric than law,"67 his image suggests that the effects of an act must be traced along a linear path. His central concern is whether a negligent act links up with a cognizable injury in an unbroken, although "uncertain and wavering" sequence of events. ${ }^{68}$ Once the stream of causation can be traced, foreseeability is implicit: "the foresight of which the courts speak assumes prevision of the explosion." 69 A bizarre, unexpected occurrence will not disrupt the chain of responsibility. Like Dworkin's judge, Andrews feels himself constrained to make a certain decision in a certain case. Cardozo, on the other hand, has proven the plausibility of Fish's view of things: the events and principles he is considering do not present him with any predetermined shape. ${ }^{70}$

65. Id. at 343,162 N.E. at 100 .

66. Id. at 349,162 N.E. at 102 (Andrews, J., dissenting).

67. Id. at 352-54, 162 N.E. at 103-04 (Andrews, J., dissenting).

68. Id. at 354, 162 N.E. at 104 (Andrews, J., dissenting).

69. Id. at 355, 162 N.E. at 104-05 (Andrews, J., dissenting).

70. Both Cardozo and Andrews cite the English case Polemis v. Furness, Withey \& Co. [1921] 3 K.B. 560, as persuasive authority for their conflicting opinions. Polemis was a similar attempt to make legal sense out of a bizarre incident. In that case an explosion in a ship's hold that occurred in the instant that stevedores passing benzine across the hold negligently dropped a plank of wood. For the judges in Polemis, once negligence was established in the stevedores' clumsy handling of the plank, the extraordinary nature of the event was inconsequential. All that was required to establish liability was proximate cause, which the court found implicit in the instantaneousness of cause (falling plank) and effect (explosion).

Andrews applies this reasoning to Palsgraf, noting that the English case articulates the law "as it should be and as it is." Palsgraf, 248 N.Y. at 350, 162 N.E. at 103 (Andrews, J., dissenting). The explosives in the package in Palsgraf, like the benzine in Polemis, for Andrews must be taken for granted. For Cardozo, Polemis may be distinguished, because in that case, damage to the ship was foreseeable. Id. at 346, 162 N.E. at 101. In Mrs. Palsgraf's case, had the package fallen on her foot, then perhaps Cardozo might have found proximate cause (just as he might have found foreseeability 
Ultimately, the divergent opinions of Cardozo and Andrews turn on their different responses to the fireworks in the package. The fact that the small, newspaper-wrapped package contains fireworks could mock any attempt to discuss the critical tort issues of foreseeability or proximate cause. The injury to Mrs. Palsgraf would not be foreseeable because the package is unmarked, or "directly" caused by the railroad because the explosion is extraordinary, in effect, magic. Cardozo does reason in this way about foreseeability, finding the events that occurred are beyond the purview of "the eye of ordinary vigilance," there can consequently be no question of negligence toward the plaintiff. Andrews, however, does nothing more with the amazing package of fireworks than fold it within the unexceptional, physical, predictable chain of events that proves the railroad negligent.

While it is in a sense a "freak" of a case, Palsgraf retains its fascination precisely because it is a puzzle that illustrates the nature of legal reasoning. ${ }^{72}$ In each set of facts on which reasonable men will differ there will be a critical element like the fireworks in the package which will either shatter or be contained in a particular logic of events. The remainder of this Comment suggests that because of the particular role they play in our legal system, judges ultimately have to fold recalcitrant evidence into one structuring of events or another. Lawyers, on the other hand, are not so constrained. In fact, their job is to point to the recalcitrance of evidence, to insist that what has been assumed by the opposition can actually explode its reasoning. As an advocate for his client, a lawyer must always be ready to question his opponent's structuring of events. $^{73}$

\section{B. Lévi-Strauss}

It has been the goal of the anthropologist Claude Lévi-Strauss to prove that the stories his tribal subjects tell are in fact profound attempts at social ordering. In terms of Lévi-Strauss' work, therefore, it seems inevitable that a literary critic like Fish and a legal theorist like Dworkin should be drawn to each other's disciplines to find a common pattern of

had the package been labeled "explosives"). But these speculations are only gestures to a tradition Cardozo does not believe applies.

71. Palsgraf, 248 N.Y. at 342,162 N.E. at 99.

72. For this reason, though Palsgraf is a favorite subject of law review articles and law scliool discussion, it is rarely cited as precedent in the courts. Professor John T. Noonan, Jr., surveys the vast Palsgraf literature in J. NoONAN, PERsons AND MASKs OF THE LAw 114-22 (1976).

73. Of course, in making a case for his client, a lawyer must also present a conclusion into which all recalcitrant evidence fits. Still, the lawyer must be ready to see a piece of evidence as innocuous or explosive depending on how he must argue for his client. The judge, on the other hand, must decide that the evidence dictates a eertain decision. These distinctions are elucidated below in the analogies likening the lawyer to Lévi-Strauss' seientist, and the judge to Lévi-Strauss' bricoleur. 
interpretive activity that explains the character of both story and law. Lévi-Strauss has also argued that for a single culture, seemingly disparate activities, like face painting and myth making, would in fact evidence a single, deep-rooted patterning of thought. Similarly, the argument that Fish and Dworkin pursue about interpretation echoes a debate that occurs in a seemingly distant context, the courtroom of Cardozo and Andrews. There is something about the chain metaphor, and discussion about whether or not it is applicable in a certain context, that must be crucial to the "tribe" of theorists that contains Andrews and Cardozo, Fish and Dworkin. What that something might be is beyond the scope of this Comment. Here it will have to be enough to observe that philosophers of interpretation, like Fish, Dworkin, and Lévi-Strauss, seem repeatedly to consider questions about what constrains decisionmakers to decide one way rather than another. Lévi-Strauss presents this question in its broadest form and thus illuminates Fish and Dworkin. Moreover, he gives us insight into why we have developed a system that uses both judges and lawyers to make important decisions.

\section{The Scientist-Bricoleur Distinction}

In The Savage Mind, ${ }^{74}$ Lévi-Strauss distinguishes between two kinds of thinkers, the "scientist" and the "bricoleur." The scientist reasons not only about facts, but also about the constructions of principles elaborated by his predecessors. The bricoleur explains events in terms of unquestioned principles. ${ }^{75}$

The scientist, Lévi-Strauss suggests, does not begin with a set of principles, but rather is prepared to allow principles to emerge to explain the facts as he observes them. The scientist sets out to distinguish a new set of events from other sets of similar events, to separate out "the contingent and the necessary."76 The scientific stance is adversarial. Scientists continually question the structurings of events proposed by other scientists. Resisting restraints imposed by current modes of thinking, the scientist continually demands new questions, looking for "that other message which might be wrested from an interlocutor in spite of his reticence in pronouncing on questions whose answers have not been re-

74. C. LÉvi-Strauss, The Savage Mind 1-33 (G. Weidenfeld trans. 1966).

75. Id. at 16-18. A bricoleur is literally a kind of jack-of-all-trades, someone who works with his hands using whatever tools and materials happen to be available, "making do with "whatever is at hand.' "Id. By his use of this colloquial term, Lévi-Strauss elevates that ordinary handyman into a metaphorical figure for a fundamental mode of reasoning. Indeed, Lévi-Strauss has claimed the bricoleur's methodology as an analogue for his own, as an anthropologist piecing together cultures from whatever artifacts he can gather, and proposes it as one pole of binary human thinking in general.

76. Id. at 21 . 
hearsed."77 In the terms developed in this Comment, the scientist is a Fishian interpreter who resists finding a chain of reasoning inevitable and, like the lawyer, is engaged in arguing that a particular message is suggested by the facts before him.

While science stands ready to question any intellectual determinism, intellectual bricolage postulates a complete, all-embracing determinism. The bricoleur, unlike the scientist, does not question structure. He systematizes elements to add up as predicted. The bricoleur aims at including new events within known structures. While the scientist looks for "that other message," the bricoleur rearranges preconstrained elements, messages transmitted in advance. Any event the bricoleur attends to must be explained in familiar terms. Lévi-Strauss points to commercial codes as examples of those messages with which the bricoleur must "make do." The codes, he contends, are "summaries of the past experience of the trade and so allow any new situation to be met economically."78 Indeed, much the same thing might be said for the entire body of common law. Like the composite structures wrought by the bricoleur, the common law is the "contingent result of all the occasions there have been to renew or enrich the stock or to maintain it."79 From this description it might be easy to conclude that for Lévi-Strauss the "bricoleur" is somehow a lesser thinker than the "scientist." But in fact it is just this modern prejudice that Lévi-Strauss intends to dispel. For Lévi-Strauss, the bricoleur's achievement, the folding of new facts into received theories, requires just as much intellectual energy and subtlety as does the scientist's task, the generating of new theories.

As the Dworkin-Fish debate and a review of the Palsgraf opinions suggest, the legal system employs both "science" and "bricolage" in the making of decisions. Lawyers, like scientists, will disagree about "facts," arguing for a version that emerges with the theory to prove a particular case. Judges, on the other hand, like bricoleurs, aim to contribute to a common body of principles that will determine holdings in all similar cases. Sometimes, of course, as in the opposing Palsgraf opinions, judges sound adversarial and therefore like lawyers. Similarly, as they argue their cases, lawyers must argue from precedent, and therefore sound judicial. However, the distinction pertains to basic, socially defined roles. In other words, it is a question of what is "lawyer-like" and "judicial," not of what individuals actually do at various moments. While the judge portrays his decision as having been determined by basic principles of law, the lawyer finds that legal principles emerge in such a way as to support the case he must argue in defense of his client.

77. Id. at 20.

78. Id.

79. Id. at 17. 


\section{The Complementarity of Science and Bricolage}

Lévi-Strauss examines a painting of Francois Clouet, ${ }^{80}$ and in his reaction to it discovers the attitudes toward objects of contemplation that characterize the bricoleur on the one hand and the scientist on the other. His discussion of the painting offers insights into the source of conflict in the Palsgraf opinions. In his self-analysis, Lévi-Strauss is in fact arguing for the sophistication of bricolage, which others would call a primitive mode of thought. Bricolage characterizes the pensée sauvage, which Lévi-Strauss, as an anthropologist and a Marxist, must study and appreciate without condescension or intellectual imperalism. ${ }^{81}$ His defense of bricolage may serve as a defense against the charge that the legal system oversimplifies complex issues, for instance "insanity," by applying law to them. He appreciates art as a bricoleur himself, Lévi-Strauss writes, when he is confronted by its neatness and wholeness, its miniaturization and perfection of a world that is not so orderly in its real dimensions. All elements of the picture prove the unity of a design, and in that it rewards the bricoleur with satisfaction as he appreciates it. But as a modern rationalist and scientist, Lévi-Strauss sees also that this picture is a manmade object, a crafted and calculated representation of things. As soon as the observer sees technique he also imagines the possibility of other techniques, other structuring of things. And in this attitude, the appreciator of art is like a scientist. Lévi-Strauss does not suggest a facile pluralism, which would permit the meaning of a work of art to be merely relative or unstable. He would agree with Fish that the work of art is "always stable and never ambiguous. It is just that it is stable in more than one direction, as a succession of interpretive assumptions gives it a succession of stable shapes." 82 In arguing that multiplicity of meaning may give rise to a better apprehension of truth, Lévi-Strauss also proves the social importance of a lawyer's ability to take either side of an issue and argues against the cynicism and sophistry many critics impute to lawyers.

80. Id. at 22-25. The picture, a portrait of Elizabeth of Austria by Francois Clouet, appears id. at 148 .

81. Id. at 22. Comparing myth as a form of bricolage with science, Lévi-Strauss observes that "[i]t is important not to make the mistake of thinking that these are two stages or phases in the evolution of knowledge. Both approaches are equally valid." Id.

82. S. Fish, Normal Circumstances, Literal Language, Direct Speech Acts, the Ordinary, the Everyday, the Obvious, What Goes without Saying, and Other Special Cases, in Is THERE A TEXT IN THIS ClAss?, supra note 24, at 268, 274; see also Gerald Graff's similarly titled "Keep off the Grass," "Drop Dead," and other Indeterminacies: A Response to Sanford Levinson, supra note 13. Though he charges that Levinson's views are "just as slippery as those of . . . Stanley Fish," id. at 413, Graff offers a Fishian account of meaning as inevitably contextual. Id. at 407-08. See also Walter Benn Michaels' insightful reading of Frigaliment Importing Co. v. B.N.S. Int'1 Sales Corp., 190 F. Supp. 116 (S.D.N.Y. 1960) and Wordsworth's "Lucy" poems in Against Formalism: Chickens and Rocks, in The State of the Language 410 (L. Michaels \& C. Ricks eds. 1980). 
When we examine legal history, as opposed to when we appreciate a painting, it is not necessarily the richness of the object observed that allows us to exercise both the bricoleur and the scientist within ourselves. Although some cases and legal questions are interesting intrinsically, much like works of art-and Palsgraf is certainly among their numbermany are not. Nevertheless, the aesthetic joy Lévi-Strauss finds in Clouet is invoked by the very structure of a legal event in which two lawyers must argue opposite possibilities convincingly before a judge or jury who must make it all "add up" to a legal whole. Like Lévi-Strauss standing before a painting by Clouet, we admire in law the spectacle of differing possible structurings reduced to a single point of view. Fish tells how we can possibly believe two lawyers are both telling the truth, and Dworkin gives us insight into why we legitimize the role of the judge who silences the cacophony with his single voice.

Like the bricoleur described by Lévi-Strauss, Dworkin's legal interpreter must fold any question within the context of an inclusive philosophy. This goal inspires the same kind of anxiety an innocent seeming package might, if one were to notice that package being carried toward the Long Island Railroad tracks on Mrs. Palsgraf's unlucky day. Andrews feels no discomfort fitting that "miraculous" explosion within a chain of ordinarily foreseeable events, but Dworkin knows that the judge's task is sometimes Herculean. Ordinary logic sometimes masks explosive questions, just as brown paper can hide dynamite. This vigilance about the correctness of interpretations is "impossible" for Fish, because for him, as for Lévi-Strauss' scientist, hypothesis and fact emerge inextricably combined in intellectual life. The interpreter necessarily believes what he thinks: no explosive discovery can invalidate his view of things because all discoveries necessarily validate the world view that makes them possible. Fish does not allow for the process of measuring and testing for truth that Dworkin describes; his interpreter cannot make the mistakes Dworkin invents Hercules to avoid. Fish, like Cardozo, can imagine no "package of dynamite." Anxiety that conclusions might be wrong seems impossible to him and he thus subtitles a chapter of his book, "How I Stopped Worrying and Learned to Love Interpretation."83

83. S. Fish, Is There a Text in This Class?, supra note 24, at 1. The title Fish uses for his Introduction plays off the movie title "Dr. Strangelove, Or How I Learned to Stop Worrying and Love the Bomb." Fish presents the defusing of the "bomb" as a willful rather than a reasoned act: he has learned to love his own interpretations, but has, in a sense, simply given up trying to prove them wrong. The metaphor invoked here and on which the Palsgraf case turned is perhaps stretched, but it is consistent. Reasoning is potentially explosive of any theory. The history of interpretation evidences as many disproofs as proofs. Like the innocuous package which injured Mrs. Palsgraf, every well-argued theory hides traces of the explosive force which someday will overturn it. Fish has decided not to worry about these future disproofs of his arguments. For now, he will love his own ideas. 


\section{CONCLUSION: GAME AND RITUAL}

Ultimately, any theory of interpretation is in some measure a defense against mistakes. History has supplied a rich catalog of mistakes for interpreters to fall into: sophistry, cynicism, solipsism, as well as simple error. It is a social necessity that we believe that, in the long run, our legal and aesthetic systems are preserving us from these dangers. Dworkin describes an environment that saves a judge from errors, and Fish does the same favor for literary critics and by analogy for lawyers. Through this debate, we find that what evolves is in fact a profound explanation of why we have created a legal system in which judges and lawyers share responsibility for determining the truth.

Law brings the interpreters described by Dworkin and Fish together into the courtroom. The interpreter, Dworkin says, is like the judge at a chess match: his role is to apply the rules of the game to the actions of the players. The Fishian interpreter is one of the players, not the referee, even when the interpreter claims otherwise:

[T] here are no inoves that are not inoves in the gaine, and this includes even the move by which one claims no longer to be a player . . [L] $]$ ike it or not, interpretation is the only game in town. ${ }^{84}$

Lévi-Strauss teaches that the game described by Dworkin and Fish is related to ritual just as science is related to bricolage. Games present the potential for many combinations of strategy and event, just as science admits the possibility of changes in principle and fact. Ritual is the "favored instance" of the game, a game replayed over and over so that its structures and meaning, like the ideas continually rediscovered by the bricoleur, can be reinforced. ${ }^{85}$ It is the referee who influences game toward ritual, who sets limits on the possible moves players can inake. In each case at law, game and ritual are, as Lévi-Strauss says, two sides of a single coin. Lawyers, the Fishian players of the game, have their sanctioned role, arguing whichever side of the issue they have been given. Judges, like Dworkin's referee, undertake to preserve the ritual by which the court will determine the right answer according to precedent. In this way, our legal system guarantees that the rights of individuals will be represented in the game by vigorous attorneys, while the cohesion of society will be preserved in the ritual dictates of the judge.

Events in the courtroom unfold with a purpose akin to a ritualistic game Lévi-Strauss describes amongst the Gahuku-Gama of New Guinea. This tribe adopted soccer from its conquerors, but often the tribal players allow the game to continue for days at a time, refusing to end the game until each side scores the same number of goals. Neither side will abate

84. Id. at 355.

85. C. LEVI-STRAUSS, supra note 74 , at 30-33. 
its individual efforts, but the activity as a whole will prove the cohesion of the tribe. The game of soccer becomes a ritual, reembodying a familiar structure because "it is the only one which results in a particular type of equilibrium between the two sides." 86

As the title of this Comment suggests, Fish and Dworkin play out their debate as the Gahuku-Gama play soccer: with opposing enthusiasm but to a tie. The series of articles, which includes titles like "Working on the Chain Gang," "Wrong Again," and "Please Don't Talk about Objectivity Any More," becomes an intellectual game as serious philosophical positions are advanced. The American legal community has been similarly tribal, playing and replaying in countless law school classrooms the events that befell Mrs. Palsgraf many years ago as she waited to board the Long Island Railroad. Mrs. Palsgraf lost her case, but became a totemic figure for law students: her individual loss fades into the ritual of society's appropriation of her. As Fish would hope, law students can still argue vigorously the two sides of Mrs. Palsgraf's case. But, as Dworkin instructs, the Palsgraf case is enshrined in the Restatement of Torts $^{87}$ as a tool for deciding similar cases. Cardozo perhaps sums up best the power of the courtroom in which lawyers appear before judges:

[T] he sordid controversies of litigants are the stuff out of which great and shining truths will ultimately be shaped. The accidental and the transitory will yield the essential and the permanent. ${ }^{38}$

Judith M. Schelly*

86. Id. at 30 .

87. RESTATEMENT OF TORTS $§ 281(\mathrm{~g})$ (1934); see also RESTATEMENT (SECOND) OF TORTS $\S 281$ (b) comment c, illustration 1 (1965).

88. B. Cardozo, The Nature of the Judicial Process 35 (1921).

* A.B. 1971, M.A. 1973, Ph.D. 1980, University of California, Berkeley; third-year student, Boalt Hall School of Law, University of California, Berkeley. 